\title{
Relative Growth of the Mangrove Crab Ucides cordatus (Linnaeus, 1763) (Crustacea, Brachyura, Ocypodidae) at Iguape, São Paulo, Brazil
}

\author{
Marcelo Antonio Amaro Pinheiro ${ }^{1 *}$ and Gustavo Yomar Hattori ${ }^{1,2}$ \\ ${ }^{1}$ Grupo de Pesquisa em Biologia de Crustáceos - CRUSTA; UNESP São Vicente; CSV; pinheiro@csv.unesp.br; Pç. \\ Infante D. Henrique, s/n; 11330-900; São Vicente - SP - Brasil. ${ }^{2}$ Programa de Pós-Graduação em Zootecnia; Área \\ de Concentração Produção Animal; UNESP Jaboticabal; FCAV; ghattori@g.mail.com; R. Prof. Paulo Donato \\ Castellane, s/n; 14884-900; Jaboticabal - SP - Brasil
}

\begin{abstract}
A total of 2,130 individuals of Ucides cordatus (1,255 males and 875 females) were captured in a mangrove forest at Iguape, São Paulo, Brazil. For each crab, the following body structures were measured: carapace (width = CW; length $=C L ;$ depth $=C D), 5^{\text {th }}$ abdominal somite $(A W)$, major chelar propodus $($ length $=P L ;$ width $=P W ;$ depth $=$ $P D)$, and $1^{\text {st }}$ and $2^{\text {nd }}$ gonopod pairs (length $=G L_{1}$ and $\left.G L_{2}\right)$. The Student " $t$ " and Snedecor " $F$ " tests were used to verify any changes in growth allometric rates during ontogeny. The relationships CLxCW, PLxCW (for both sexes), $G L_{1} x C W$ and $G L_{2} x C W$ (males) and $A W x C W$ (females), showed a better fit by two equations for the juvenile and adult phases $(p<0.01)$. The inflexion point size between regression lines, indicated by each morphometric relationship, allowed to propose four morphotypes for U. cordatus. Males were classified in juvenile $(\mathrm{CW} \leq 32 \mathrm{~mm})$, pre-puberty $(32 \leq C W \leq 51 \mathrm{~mm})$, sub-adult $(51 \leq C W \leq 59 \mathrm{~mm})$ and adult $(C W>59 \mathrm{~mm})$. Females showed a similar size interval: (juvenile $C W \leq 39 \mathrm{~mm}$, pre-puberty $39 \leq C W \leq 53 \mathrm{~mm}$, sub-adult $53 \leq C W \leq 58 \mathrm{~mm}$, adult $C W>58$ $m m)$.
\end{abstract}

Key words: Relative growth, Brachyura, Ocypodidae, Ucides

\section{INTRODUCTION}

Ucides cordatus (Linnaeus, 1763) is a semiterrestrial crab that lives only in mangrove areas and occurs throughout the western Atlantic Ocean, from Florida, USA to Santa Catarina State, Brazil (Melo, 1996). Because of its large size and tasty meat, this crab has been exploited in many parts of Brazil (Rodrigues et al., 2000). The relative growth of several species of ocypodids has been studied (Crane, 1941; Barnes, 1968; Haley, 1969, 1973; Miller, 1973; von Hagen, 1987), including fiddler crabs of the genus Uca (Frith and
Brunmeister, 1983; Negreiros-Fransozo et al., 2003). The biometric studies of $U$. cordatus have emphasized dimorphism of the chelae (Santos and Garcia-Mendes, 1982), or allometric growth of the carapace (Branco, 1993). Recently, Dalabona et al. (2005) described the relative growth of this species from a mangrove area on southern Brazilian coast. Ontogeny in brachyurans is marked by morphological changes related to sex and puberty, which were first observed by Huxley $(1924,1950)$. Biometric changes in the chelae, abdomen and pleopods are evident in both sexes and in the developmental stages of crustaceans, principally

\footnotetext{
${ }^{*}$ Author for correspondence
} 
during the transition from the immature to the mature stage, when the puberty molt occurs (Hartnoll, 1974, 1982). Analyses of these changes allow mathematical equations to be determined that could be used to convert biometric variables (Pinheiro and Fransozo, 1993), estimate the size at puberty (Pinheiro and Fransozo, 1998), and also to identify brachyuran species (Huber, 1985).

The present study describes the relative growth of $U$. cordatus, analyzing the biometric relationships between the carapace (length and width), the major chelar propodus (length, width and depth) and the abdomen for each sex. For males, the lengths of the first and second pair of gonopods were also analyzed. These data were used to identify possible changes in the allometric growth rates between development phases (juvenile and adult), and to propose a description of the morphotypes, based on the size estimated at the puberty molt.

\section{MATERIALS AND METHODS}

Individuals of $U$. cordatus were captured monthly from September 1998 to September 2000, in mangrove forests near Icapara Bar $\left(24^{\circ} 41^{\prime} \mathrm{S}\right)$, Iguape, state of São Paulo, Brazil, by digging or trapping. The specimens were kept frozen separately until the biometric analysis. Each crab was sexed, and then measured with a vernier caliper to the nearest $0.05 \mathrm{~mm}$. The following dimensions were selected for morphometric analysis: carapace $(\mathrm{CW}=$ width; $\mathrm{CL}=$ length; $\mathrm{CD}$ $=$ depth $)$, abdomen $\left(\mathrm{AW}=\right.$ width of $5^{\text {th }}$ somite $)$, major chelar propodus $(\mathrm{PL}=$ length; $\mathrm{PW}=$ width; $\mathrm{PD}=$ depth $)$ and male gonopods $\left(\mathrm{GL}_{1}\right.$ and $\mathrm{GL}_{2}=$ lengths of the $1^{\text {st }}$ and $2^{\text {nd }}$ pair of gonopods, respectively) (Fig. 1). All the biometric relationships were submitted to regression analyses by a power function $\left(y=a x^{b}\right)$ (Huxley, 1950) with respect to the variable $\mathrm{CW}$. The biometric relationships were verified by a coefficient of determination $\left(\mathrm{R}^{2}\right)$, while Snedecor's F test $(\alpha=0.01)$ (Sokal and Rolf, 1995) was used to verify the presence of one or two regression lines for the empirical points. All the biometric relationships were submitted to MATURE 1 (Somerton, 1980) or MATURE 2 software (Somerton and MacIntosh, 1983), to identify the inflection point at puberty size.

The allometric growth rate of each developmental phase was established by the "b" value, and considered as isometry $(\mathrm{b}=1)$, positive allometric (b $>1)$ or negative allometric $(b<1)$. Student " $t$ " test was used to verify the significance of this value related to the unit $(\alpha=0.01)$.

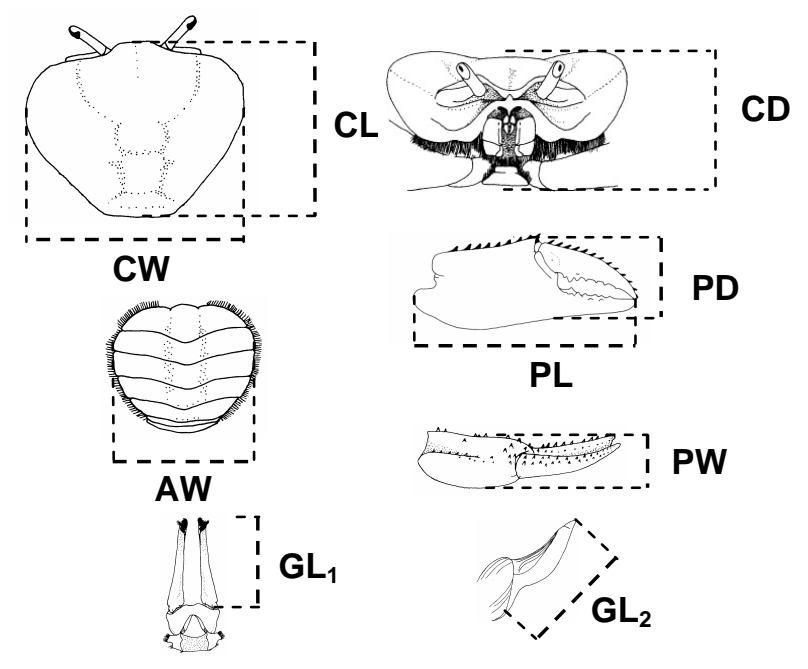

Figure 1 - $U$. cordatus (Linnaeus, 1763). Measurements used to analyze relative growth $(\mathrm{CW}=$ carapace width; $\mathrm{CL}=$ carapace length $\mathrm{CD}=$ carapace depth; $\mathrm{PL}=$ chelar propodus length; $\mathrm{PD}=$ propodus depth; $\mathrm{PW}=$ propodus width; $\mathrm{AW}=$ width at fifth abdominal somite, for females; GL1 = first gonopod pair length; GL2 = second gonopod pair length). 
The morphometric relationships, which showed allometric growth rate changes according to the MATURE software, had their biometric equation constants submitted to a "t" (z) test (Santos, 1978), to determine if juveniles of each sex could be clustered by a single equation. The same procedure was used for adults.

\section{RESULTS}

Table 1 lists all the variables obtained by biometric analyses of 2,130 specimens $(1,255$ males and 785 females). All the equations calculated for biometric relationships showed a close fit, with the coefficient of determination higher than 0.9 in $67.6 \%$ of all cases (Table 2). The CLxCW relationship evidenced negative allometric growth for both males $(\mathrm{t}=11.4$; $\mathrm{p}<0.01)$ and females $(\mathrm{t}=2.9 ; \mathrm{p}<0.01)$. Even then, the constant " $b$ " showed a strong tendency toward isometry $\left(b_{\text {males }}=0.95 ; b_{\text {females }}=0.96\right)$. The empirical points of each sex were better fitted by two equations, with changes in allometric rates during ontogeny $\left(\mathrm{F}_{\text {males }}=6.9 ; \mathrm{F}_{\text {females }}=6.6\right.$; $\mathrm{p}<0.01)$. The comparison of the cut point size between juvenile and adult was similar in the size estimated $\left(\mathrm{CW}_{\text {males }}=59.1 \mathrm{~mm}\right.$, Fig. $2-\mathrm{A} ; \mathrm{CW}_{\text {females }}$ $=58.2 \mathrm{~mm}$; Fig. 2-B). The juveniles of each sex tended toward isometry, but this tendency was statistically significant only for females $\left(b_{\text {females }}=\right.$ $0.99 ; \mathrm{t}=0.2 ; \mathrm{p}>0.01)$. The adults showed negative allometry $\left(b_{\text {males }}=0.89 ; b_{\text {females }}=0.84 ; \mathrm{p}<0.01\right)$, which could be represented by a single equation (p>0.05) (Table 3).

Table 1 - U. cordatus (Linnaeus, 1763). Summary statistics for the biometric analyses used in the present study (CL = carapace length $; \mathrm{CW}=$ width $; \mathrm{CD}=$ depth $\mathrm{PL}=$ major chelar propodus length $\mathrm{PD}=$ depth, $\mathrm{PW}=$ width; $\mathrm{AW}=$ abdominal width at fifth somite; $\mathrm{GL}_{1}=1^{\text {st }}$ gonopod pair length, $\mathrm{GL}_{2}=2^{\text {nd }}$ gonopod pair length).

\begin{tabular}{|c|c|c|c|c|c|}
\hline Dimension & $\mathbf{N}$ & Sex & Min. & Max. & Average \pm SD \\
\hline \multirow{4}{*}{$\mathrm{CW}(\mathrm{mm})$} & 1,255 & Male & 16.70 & 83.40 & $51.80 \pm 11.62$ \\
\hline & 875 & Female & 14.80 & 78.10 & $47.04 \pm 9.26$ \\
\hline & 2,130 & Total & 14.80 & 83.40 & $49.85 \pm 10.96$ \\
\hline & 1,255 & Male & 13.50 & 61.55 & $38.93 \pm 8.40$ \\
\hline \multirow[t]{2}{*}{$\mathrm{CL}(\mathrm{mm})$} & 875 & Female & 11.85 & 57.35 & $36.06 \pm 7.05$ \\
\hline & 2,130 & Total & 11.85 & 61.55 & $37.75 \pm 7.99$ \\
\hline \multirow[t]{2}{*}{$\mathrm{CD}(\mathrm{mm})$} & 977 & Male & 12.00 & 52.45 & $32.79 \pm 6.71$ \\
\hline & 673 & Female & 9.75 & 47.70 & $31.44 \pm 6.34$ \\
\hline \multirow[t]{2}{*}{$\mathrm{PL}(\mathrm{mm})$} & 714 & Male & 11.35 & 88.50 & $45.06 \pm 14.15$ \\
\hline & 660 & Female & 8.80 & 50.95 & $33.08 \pm 7.72$ \\
\hline \multirow[t]{2}{*}{$\mathrm{PW}(\mathrm{mm})$} & 670 & Male & 3.15 & 23.00 & $12.53 \pm 3.63$ \\
\hline & 462 & Female & 2.25 & 14.70 & $9.49 \pm 2.09$ \\
\hline \multirow[t]{2}{*}{$\mathrm{PD}(\mathrm{mm})$} & 671 & Male & 5.80 & 36.90 & $21.81 \pm 5.85$ \\
\hline & 463 & Female & 4.70 & 26.30 & $17.67 \pm 3.74$ \\
\hline \multirow[t]{2}{*}{$\mathrm{AW}(\mathrm{mm})$} & 1,261 & Male & 4.90 & 20.60 & $13.58 \pm 1.97$ \\
\hline & 862 & Female & 4.40 & 44.05 & $28.05 \pm 6.68$ \\
\hline $\mathrm{GL}_{1}(\mathrm{~mm})$ & 677 & Male & 7.60 & 31.85 & $20.99 \pm 4.94$ \\
\hline $\mathrm{GL}_{2}(\mathrm{~mm})$ & 663 & Male & 1.15 & 4.82 & $3.20 \pm 0.77$ \\
\hline
\end{tabular}

The $\mathrm{CDxCW}$ relationship did not reveal any change in growth rate during ontogeny. This relationship indicated isometry for females $(\mathrm{t}=$ $0.16 ; \mathrm{p}>0.01)$ and negative allometry for males $(\mathrm{t}$ $=15.2 ; \mathrm{p}<0.01)$.

The points of the PLxCW relationship showed a better fit for two equations in both sexes $\left(\mathrm{F}_{\text {males }}=\right.$ $\left.4.9 ; \mathrm{F}_{\text {females }}=11.2 ; \mathrm{p}<0.01\right)$, the inflexion point was $51.3 \mathrm{~mm}$ for males (Fig. 3-A) and $52.6 \mathrm{~mm}$ for females (Fig. 3-B). The sexes differed in the degree of allometry: males showed positive allometric growth $\left(b_{\text {adults }}=1.47\right)$, whereas growth in females was isometric $\left(b_{\text {adults }}=1.01\right)$. 
Table 2 - U. cordatus (Linnaeus, 1763). Regression analyses of each morphometric dimension: carapace $(\mathrm{CL}=$ length; $\mathrm{CW}=$ width $\mathrm{CD}=$ depth), major chelar propodus $(\mathrm{PL}=$ length; $\mathrm{PD}=$ depth and $\mathrm{PW}=$ width $)$, abdomen $(\mathrm{AW}=$ abdominal width at fifth somite $)$ and gonopods $\left(\mathrm{GL}_{1}=1^{\text {st }}\right.$ pair length, $\mathrm{GL}_{2}=2^{\text {nd }}$ pair length $)$ and respective sex phase (YM = young males; $\mathrm{AM}=$ adult males; $\mathrm{TM}=$ total of males; $\mathrm{YF}=$ young females; $\mathrm{AF}=$ adult females; $\mathrm{TF}=$ total of females $)$ and allometric growth rate $(\mathrm{AL}=$ allometric level; $0=$ isometry; $+=$ allometric positive; $-=$ allometric negative).

\begin{tabular}{|c|c|c|c|c|c|c|c|c|c|}
\hline Relationship & $\begin{array}{c}\text { Sex } \\
\text { Phase }\end{array}$ & $\mathbf{N}$ & $\begin{array}{c}\text { Power function } \\
\left(\mathbf{v}=a x^{b}\right)\end{array}$ & $\begin{array}{c}\text { Linearized equation } \\
(\ln v=\ln a+b \ln x)\end{array}$ & $\mathbf{r}^{2}$ & $t(\mathrm{~b}=1)^{(1)}$ & $\mathbf{A L}$ & $\begin{array}{c}\text { Somerton's } \\
\text { F-test }\end{array}$ & Cut point (mm) \\
\hline \multirow{7}{*}{ CLxCW } & YM & 902 & $\mathrm{CL}=0.869 \mathrm{CW}^{0.964}$ & $\operatorname{lnCL}=-0.1405+0.964 \ln C W$ & 0.96 & $5.90 *$ & - & \multirow{3}{*}{$6.89 *$} & \multirow{3}{*}{59.1} \\
\hline & MA & 353 & $\mathrm{CL}=1.17 \mathrm{CW}^{0.892}$ & $\operatorname{lnCL}=0.156+0.892 \operatorname{lnCW}$ & 0.82 & $14.80 *$ & -- & & \\
\hline & MT & 1255 & $\mathrm{CL}=0.9064 \mathrm{CW}^{0.953}$ & $\operatorname{lnCL}=-0.0983+0.953 \operatorname{lnCW}$ & 0.98 & $11.40 *$ & - & & \\
\hline & YF & 749 & $\mathrm{CL}=0.772 \mathrm{CW}^{0.999}$ & $\operatorname{lnCL}=-0.259+0.999 \operatorname{lnCW}$ & 0.97 & $0.21 \mathrm{~ns}$ & 0 & & \\
\hline & $\mathrm{AF}$ & 126 & $\mathrm{CL}=1.505 \mathrm{CW}^{0.835}$ & $\operatorname{lnCL}=0.4088+0.835 \operatorname{lnCW}$ & 0.66 & $3.05 *$ & - & $6.62 *$ & 58.2 \\
\hline & $\mathrm{TF}$ & 875 & $\mathrm{CL}=0.8106 \mathrm{CW}^{0.985}$ & $\operatorname{lnCL}=-0.2099+0.985 \operatorname{lnCW}$ & 0.98 & $2.90 *$ & - & & \\
\hline & $\overline{\mathrm{AM}+\mathrm{AF}}$ & 479 & $\mathrm{CL}=1.3371 \mathrm{CW}^{0.861}$ & $\operatorname{lnCL}=0.291+0861 \ln C W$ & 080 & $10.2 *$ & -- & - & - \\
\hline \multirow[b]{2}{*}{ CDxCW } & $\mathrm{TF}$ & 673 & $\mathrm{CD}=0.666 \mathrm{CW}^{0.999}$ & $\operatorname{lnCD}=-0.4061+0.9991 \mathrm{lnCW}$ & 0.97 & $0.16 \mathrm{~ns}$ & 0 & $3.24 \mathrm{~ns}$ & - \\
\hline & MT & 977 & $\mathrm{CD}=0.878 \mathrm{CW}^{0.917}$ & $\operatorname{lnCD}=-0.1304+0.917 \ln C W$ & 0.97 & $15.21 *$ & - & $1.62 \mathrm{~ns}$ & - \\
\hline \multirow{6}{*}{ PLxCW } & YM & 386 & $\mathrm{PL}=0.199 \mathrm{CW}^{1.37}$ & $\operatorname{lnPL}=-1.62+1.37 \operatorname{lnCW}$ & 0.98 & $24.20 *$ & + & \multirow{3}{*}{$4.89 *$} & \multirow{3}{*}{51.3} \\
\hline & $\mathrm{AM}$ & 328 & $\mathrm{PL}=0.134 \mathrm{CW}^{1.47}$ & $\ln \mathrm{PL}=-2.0095+1.47 \operatorname{lnCW}$ & 0.91 & $18.70 *$ & ++ & & \\
\hline & MT & 714 & $\mathrm{PL}=0.171 \mathrm{CW}^{1.41}$ & $\operatorname{lnPL}=-1.77+1.41 \operatorname{lnCW}$ & 0.95 & $49.80 *$ & ++ & & \\
\hline & YF & 508 & $\mathrm{PL}=0.312 \mathrm{CW}^{1.22}$ & $\operatorname{lnPL}=-1.16+1.22 \ln C W$ & 0.93 & $14.80 *$ & + & \multirow{3}{*}{$11.16 *$} & \multirow{3}{*}{52.6} \\
\hline & $\mathrm{AF}$ & 152 & $\mathrm{PL}=0.702 \mathrm{CW}^{1.012}$ & $\operatorname{lnPL}=-0.354+1.012 \operatorname{lnCW}$ & 0.73 & $0.25 \mathrm{~ns}$ & 0 & & \\
\hline & $\mathrm{TF}$ & 660 & $\mathrm{PL}=0.360 \mathrm{CW}^{1.18}$ & $\operatorname{lnPL}=-1.022+1.18 \operatorname{lnCW}$ & 0.96 & $18.90 *$ & + & & \\
\hline \multirow{3}{*}{ PWxCW } & $\begin{array}{l}\text { YM } \\
\text { AM } \\
\text { MT }\end{array}$ & $\begin{array}{l}555 \\
115 \\
670\end{array}$ & $\begin{array}{l}\mathrm{PW}=0.0626 \mathrm{CW}^{1.34} \\
\mathrm{PW}=0.3284 \mathrm{CW}^{0.94} \\
\mathrm{PW}=0.0748 \mathrm{CW}^{1.29}\end{array}$ & $\begin{array}{l}\ln P W=2.77+1.34 \ln C W \\
\ln P W=1.11+0.94 \ln C W \\
\ln P W=2.59+1.29 \ln C W\end{array}$ & $\begin{array}{l}0.95 \\
0.65 \\
0.96\end{array}$ & $\begin{array}{l}25.23 * \\
0.89 \mathrm{~ns} \\
28.81 *\end{array}$ & $\begin{array}{l}+ \\
0 \\
+\end{array}$ & $23.99 *$ & 63.8 \\
\hline & $\begin{array}{l}\text { YF } \\
\text { AF } \\
\text { TF }\end{array}$ & $\begin{array}{l}326 \\
136 \\
462\end{array}$ & $\begin{array}{l}\mathrm{PW}=0.0953 \mathrm{CW}^{1.20} \\
\mathrm{PW}=0.2969 \mathrm{CW}^{0.91} \\
\mathrm{PW}=0.129 \mathrm{CW}^{1.11}\end{array}$ & $\begin{array}{l}\ln P W=2.35+1.20 \ln C W \\
\ln P W=1.21+0.91 \ln C W \\
\ln P W=2.05+1.11 \ln C W\end{array}$ & $\begin{array}{l}0.91 \\
0.63 \\
0.94\end{array}$ & $\begin{array}{l}9.53 * \\
1.56 \mathrm{~ns} \\
8.51 *\end{array}$ & $\begin{array}{l}+ \\
0 \\
+\end{array}$ & \multirow[b]{3}{*}{$16.18 *$} & 51.4 \\
\hline & $\overline{\mathrm{AM}+\mathrm{AF}}$ & 251 & $\mathrm{PW}=0.0123 \mathrm{CW}^{1.70}$ & $\ln P W=-4.40+1.70 \ln C W$ & 0.89 & $3.58 *$ & ++ & & - \\
\hline \multirow{2}{*}{ PDxCW } & $\begin{array}{l}\text { YM } \\
\text { AM } \\
\text { MT }\end{array}$ & $\begin{array}{l}556 \\
115 \\
671\end{array}$ & $\begin{array}{l}\mathrm{PD}=0.157 \mathrm{CW}^{1.25} \\
\mathrm{PD}=0.4643 \mathrm{CW}^{0.99} \\
\mathrm{PD}=0.1802 \mathrm{CW}^{1.21}\end{array}$ & $\begin{array}{l}\ln P D=1.85+1.25 \ln C W \\
\operatorname{lnPD}=0.77+0.991 n C W \\
\ln P D=1.71+1.21 \operatorname{lnCW}\end{array}$ & $\begin{array}{l}0.95 \\
0.70 \\
0.97\end{array}$ & $\begin{array}{l}22.80 * \\
0.28 \mathrm{~ns} \\
25.37 *\end{array}$ & $\begin{array}{l}+ \\
0 \\
+\end{array}$ & & 64.0 \\
\hline & $\begin{array}{l}\mathrm{YF} \\
\mathrm{AF} \\
\mathrm{TF}\end{array}$ & $\begin{array}{l}324 \\
139 \\
463\end{array}$ & $\begin{array}{l}\mathrm{PD}=0.1892 \mathrm{CW}^{1.18} \\
\mathrm{PD}=0.5897 \mathrm{CW}^{0.89} \\
\mathrm{PD}=0.2545 \mathrm{CW}^{1.10}\end{array}$ & $\begin{array}{l}\ln P D=1.67+1.18 \ln C W \\
\ln P D=0.53+0.89 \operatorname{lnCW} \\
\ln P D=1.37+1.10 \ln C W\end{array}$ & $\begin{array}{l}0.91 \\
0.71 \\
0.95\end{array}$ & $\begin{array}{l}8.71 * \\
2.28 * \\
7.99 *\end{array}$ & $\begin{array}{l}+ \\
- \\
+\end{array}$ & \multirow{5}{*}{$229.77 *$} & 51.5 \\
\hline \multirow{4}{*}{$\mathrm{AW} \times \mathrm{CW}$} & MT & 1261 & $\mathrm{AW}=0.399 \mathrm{CW}^{0.876}$ & $\ln \mathrm{AW}=-0.918+0.876 \ln \mathrm{CW}$ & 0.97 & $28.60 *$ & -- & & - \\
\hline & YF & 163 & $\mathrm{AW}=0.0325 \mathrm{CW}^{1.79}$ & $\ln \mathrm{AW}=-3.43+1.79 \ln \mathrm{CW}$ & 0.91 & $17.80 *$ & +++ & & \\
\hline & $\mathrm{AF}$ & 699 & $\mathrm{AW}=0.4075 \mathrm{CW}^{1.101}$ & $\ln A W=-0.898+1.101 \ln C W$ & 0.93 & $8.64 *$ & + & & 39.1 \\
\hline & $\mathrm{TF}$ & 862 & $\mathrm{AW}=0.2007 \mathrm{CW}^{1.28}$ & $\ln A W=-1.606+1.28 \ln C W$ & 0.93 & $24.3 *$ & + & & \\
\hline \multirow{3}{*}{$\mathrm{GL}_{1} \times \mathrm{CW}$} & YM & 21 & $\mathrm{GL}_{1}=0.0728 \mathrm{CW}^{1.49}$ & $\operatorname{lnGL} L_{1}=-2.62+1.49 \operatorname{lnCW}$ & 0.79 & $2.80 *$ & +++ & \multirow{3}{*}{$40.96 *$} & \multirow{3}{*}{31.9} \\
\hline & $\mathrm{AM}$ & 656 & $\mathrm{GL}_{1}=0.489 \mathrm{CW}^{0.949}$ & $\operatorname{lnGL} L_{1}=-0.717+0.9491 \mathrm{nCW}$ & 0.98 & $9.37 *$ & - & & \\
\hline & MT & 677 & $\mathrm{GL}_{1}=0.451 \mathrm{CW}^{0.969}$ & $\operatorname{lnGL}_{1}=-0.796+0.9691 \mathrm{nCW}$ & 0.98 & $5.59 *$ & - & & \\
\hline \multirow{3}{*}{$\mathrm{GL}_{2} \mathrm{xCW}$} & YM & 315 & $\mathrm{GL}_{2}=0.0322 \mathrm{CW}^{1.18}$ & $\operatorname{lnGL} L_{2}=-3.44+1.18 \operatorname{lnCW}$ & 0.85 & $5.90 *$ & + & \multirow{3}{*}{$59.57 *$} & \multirow{3}{*}{50.7} \\
\hline & $\mathrm{AM}$ & 348 & $\mathrm{GL}_{2}=0.148 \mathrm{CW}^{0.786}$ & $\operatorname{lnGL}_{2}=-1.91+0.786 \operatorname{lnCW}$ & 0.79 & $14.80 *$ & -- & & \\
\hline & MT & 663 & $\mathrm{GL}_{2}=0.0626 \mathrm{CW}^{0.995}$ & $\operatorname{lnGL} L_{2}=-2.77+0.995 \operatorname{lnCW}$ & 0.93 & $11.40 \mathrm{~ns}$ & 0 & & \\
\hline
\end{tabular}

(1) $\mathrm{t}$-test $\mathrm{H}_{\mathrm{o}}=\overline{\beta=1 ;}=\mathrm{p}<0.01 ; \mathrm{ns}=\mathrm{p}>0.01$. 

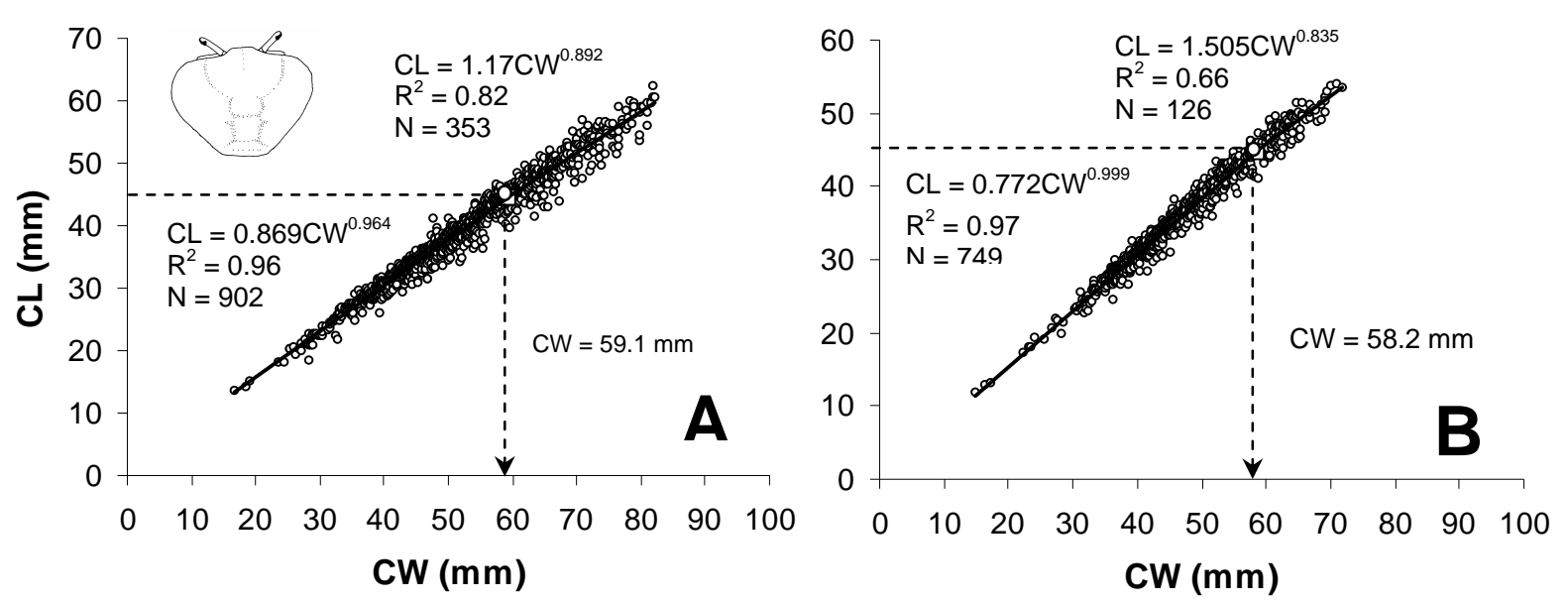

Figure 2 - U. cordatus (Linnaeus, 1763). Regression analysis of carapace length (CL) against carapace width (CW) for males (A) and females (B).

Table 3 - U. cordatus (Linnaeus, 1763). Results of Student's " $\mathrm{t}$ " test analyses for relative growth equation constants ("a" and "b") for males (YM = young males; $\mathrm{AM}=$ adult males; TM = total of males) and females (YF = young females; $\mathrm{AF}=$ adult females; $\mathrm{TF}=$ total of females $)$ for morphometric dimension: carapace $(\mathrm{CL}=$ length; $\mathrm{CW}=$ width; $\mathrm{CD}=$ depth), major chelar propodus $(\mathrm{PL}=$ length; $\mathrm{PD}=$ depth and $\mathrm{PW}=$ width $)$ and abdomen $(\mathrm{AW}=$ abdominal width at fifth somite).

\begin{tabular}{|c|c|c|c|c|c|c|c|}
\hline \multirow{2}{*}{ Relationship } & \multirow{2}{*}{$\begin{array}{c}\text { Sex } \\
\text { phase }\end{array}$} & \multirow[t]{2}{*}{$\mathbf{N}$} & \multirow[t]{2}{*}{$\mathbf{a}$} & \multirow[t]{2}{*}{ b } & \multirow{2}{*}{$\begin{array}{c}\text { CW average } \\
(\mathrm{mm})\end{array}$} & \multicolumn{2}{|c|}{ Student t-test } \\
\hline & & & & & & $t$ angle "b" & t linear "a" \\
\hline \multirow{4}{*}{ CLxCW } & YM & 902 & -0.1405 & 0.964 & 46.11 & $4.64 *$ & $2.14 \mathrm{~ns}$ \\
\hline & $\mathrm{AF}$ & 749 & -0.259 & 0.999 & 44.38 & & \\
\hline & $\mathrm{AM}$ & 353 & 0.156 & 0.892 & 66.33 & $1.11 \mathrm{~ns}$ & $1.46 \mathrm{~ns}$ \\
\hline & $\mathrm{AF}$ & 126 & 0.4088 & 0.835 & 62.89 & & \\
\hline \multirow[t]{2}{*}{ CDxCW } & $\mathrm{TM}$ & 977 & -0.1304 & 0.917 & 51.84 & $12.89 *$ & $4.26 *$ \\
\hline & $\mathrm{AF}$ & 673 & -0.4061 & 0.999 & 47.37 & & \\
\hline \multirow{4}{*}{ PLxCW } & YM & 386 & -1.62 & 1.37 & 42.85 & $8.26 *$ & $4.17 *$ \\
\hline & $\mathrm{AF}$ & 508 & -1.16 & 1.22 & 42.35 & & \\
\hline & $\mathrm{AM}$ & 328 & -2.0095 & 1.47 & 60.91 & $8.61 *$ & $6.33 *$ \\
\hline & $\mathrm{AF}$ & 152 & -0.354 & 1.012 & 59.16 & & \\
\hline \multirow{4}{*}{ PWxCW } & YM & 555 & 2.77 & 1.34 & 48.19 & $20.41 *$ & $9.44 *$ \\
\hline & $\mathrm{AF}$ & 326 & 2.35 & 1.2 & 42.33 & & \\
\hline & $\mathrm{AM}$ & 115 & 1.11 & 0.94 & 70.55 & $1.496 \mathrm{~ns}$ & $0.945 \mathrm{~ns}$ \\
\hline & $\mathrm{AF}$ & 136 & 1.21 & 0.91 & 58.83 & & \\
\hline \multirow{4}{*}{ PDxCW } & YM & 556 & 1.85 & 1.25 & 48.34 & $6.51 *$ & $2.69 \mathrm{~ns}$ \\
\hline & $\mathrm{AF}$ & 324 & 1.67 & 1.18 & 42.51 & & \\
\hline & $\mathrm{AM}$ & 115 & 0.77 & 0.99 & 70.27 & $3.31 *$ & $1.54 *$ \\
\hline & $\mathrm{AF}$ & 139 & 0.53 & 0.89 & 58.78 & & \\
\hline \multirow{4}{*}{ AWxCW } & TM & 1,261 & -0.918 & 0.876 & 51.72 & $72.46 *$ & $44.21 *$ \\
\hline & $\mathrm{AF}$ & 163 & -3.43 & 1.79 & 34.90 & & \\
\hline & $\mathrm{TM}$ & 1,261 & -0.918 & 0.876 & 51.72 & $45.84 *$ & $0.469 \mathrm{~ns}$ \\
\hline & $\mathrm{AF}$ & 699 & -0.898 & 1.101 & 49.84 & & \\
\hline
\end{tabular}

$*=\mathrm{p}<0.01 ; \mathrm{ns}=\mathrm{p}>0.01$. 

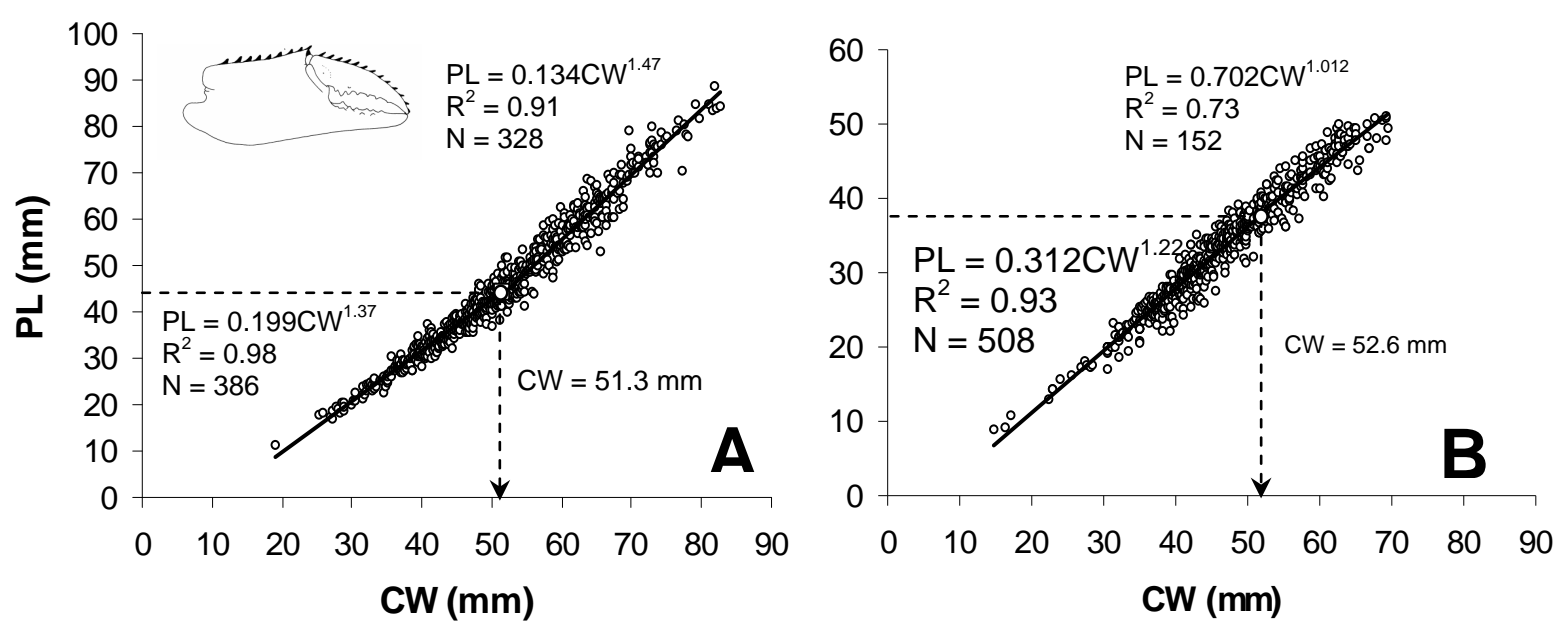

Figure 3 - U. cordatus (Linnaeus, 1763). Regression analysis of chelar propodus length (PL) against carapace width $(\mathrm{CW})$ for males $(\mathrm{A})$ and females $(\mathrm{B})$.

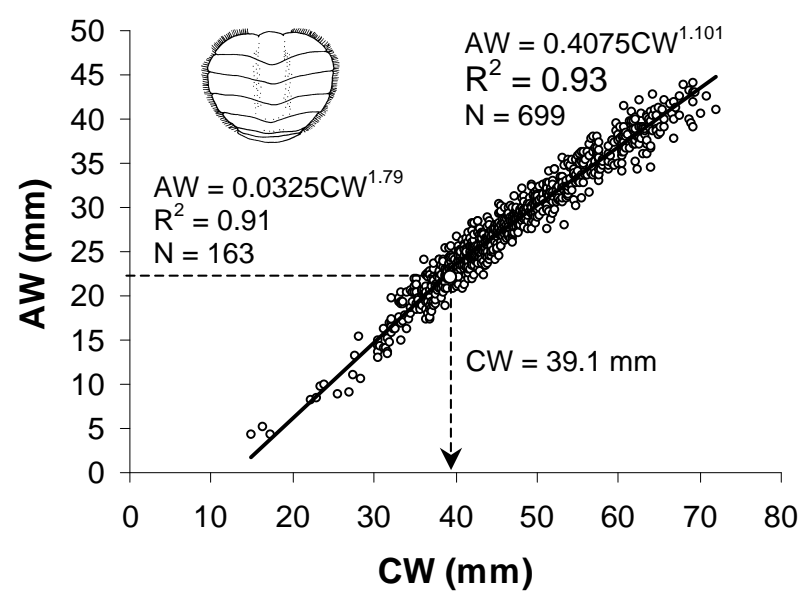

Figure 4 - $U$. cordatus (Linnaeus, 1763). Regression analysis of fifth abdominal width (AW) against carapace width $(\mathrm{CW})$ for juvenile females $(\mathrm{N}=163)$ and adults $(\mathrm{N}=699)$.

The PWxCW relationship for both sexes was represented by two equations, $\left(F_{\text {males }}=23.99 ; F_{\text {females }}\right.$ $=17.38 ; \mathrm{p}<0.01)$, with the cut points at $63.8 \mathrm{~mm}$ (males) and $51.4 \mathrm{~mm}$ (females). The degree of allometry did not differ between the sexes; it was positive allometric for juveniles $\left(b_{\text {males }}=1.34\right.$; $\left.\mathrm{b}_{\text {females }}=1.20\right)$ and isometric in adults $\left(\mathrm{b}_{\text {males }}=0.94\right.$; $\left.b_{\text {females }}=0.91\right)$. The adult phase could be clustered and represented by one equation ( $p>0.05$ ) (Table 3 ). For both sexes, the PDxCW relationship was best expressed by two equations $\left(\mathrm{F}_{\text {males }}=16.2 ; \mathrm{F}_{\text {females }}=\right.$
19.2; $\mathrm{p}<0.01)$, with differences in the degree of allometry between the developmental phases. In juveniles, growth was positive allometric, more strongly in males $\left(b_{\text {males }}=1.25 ; b_{\text {females }}=1.18\right)$, but showing a different growth pattern in the adult phase. Isometry was verified for males $(b=0.99)$ and negative allometry for females $(b=0.89)$. In no phase of development, the biometric variable of this relationship could be clustered $(\mathrm{p}<0.05)$.

The AWxCW relationship for males showed negative allometric growth $(\mathrm{b}=0.88)$, best fitted by 
a single regression line $(\mathrm{F}=0.53 ; \mathrm{p}>0.01)$. Contrariwise, females showed positive allometry and could be represented by two lines $(\mathrm{F}=229.8$; $\mathrm{p}<0.01$ ), with the inflexion point at $39.1 \mathrm{~mm}$ (Fig. 4). The $\mathrm{GL}_{1} \mathrm{xCW}$ was best fitted by two regression lines $(F=40.9 ; p<0.01)$ and was characterized by positive allometric growth in the juvenile phase (b $=1.49)$ and negative allometry in adults $(b=0.95)$, with the cut point at $31.9 \mathrm{~mm}$. The same pattern occurred for the $\mathrm{GL}_{2} \mathrm{xCW}$ relationship $(\mathrm{F}=59.6$; $\mathrm{p}<0.01$ ), with the inflexion point $58.9 \%$ higher than estimated by the $\mathrm{GL}_{1} \mathrm{xCW}(50.7 \mathrm{~mm})$. The inflexion point sizes obtained for all the morphometric relationships allowed us to propose four morphotypes for each sex. Males were classified in juvenile ( $\mathrm{CW} \leq 32 \mathrm{~mm}$ ), pre-puberty $(32 \leq \mathrm{CW} \leq 51 \mathrm{~mm})$, sub-adult $(51 \leq \mathrm{CW} \leq 59$ $\mathrm{mm})$ and adult $(\mathrm{CW}>59 \mathrm{~mm})$, with a similar division for females (juvenile $\mathrm{CW} \leq 39 \mathrm{~mm}$, prepuberty $39 \leq \mathrm{CW} \leq 53 \mathrm{~mm}$, sub-adult $53 \leq \mathrm{CW} \leq$ $58 \mathrm{~mm}$, and adult $\mathrm{CW}>58 \mathrm{~mm}$ ).

\section{DISCUSSION}

In the studies on relative growth, Hartnoll (1974, $1978,1982)$ observed that morphometric variables related to the carapace were characterized by isometry, which was represented by some authors as an interval of $0.9 \leq b \leq 1.1$ (Kuris et al., 1987; Pinheiro and Fransozo, 1993). However, the use of statistical tests invalidated the hypothesis of isometric growth for this biometric relationship in certain species (Finney and Abele, 1981; Davidson and Marsden, 1987). This growth pattern was demonstrated by Barnes (1968) in biometric analyses of the ocypodids Macrophthalmus spp., and it was also observed in the present study.

In many of the brachyurans that have been studied, the carapace relationships did not indicate a change in growth pattern during ontogeny. This body structure has not been used to estimate the size at morphological maturity (Somerton, 1980; Somerton and MacIntosh, 1983; Pinheiro and Fransozo, 1998). However, Aguilar and Spina (1988) observed for females of the callapid Mursia gaudichaudi (H. Milne Edwards, 1837), a synchrony between the size at onset of sexual maturity and the inflexion point size obtained by CLxCW. A similar synchrony was not seen in $U$. cordatus, since the size at gonadal maturity was lower than indicated by the CLxCW relationship
$\left(\mathrm{CW}_{\text {males }}=51 \mathrm{~mm}\right.$ and $\mathrm{CW}_{\text {females }}=43 \mathrm{~mm}$, according to Hattori and Pinheiro, submitted). The greater increment of CW size from $59 \mathrm{~mm}$ might be associated with the increase in the size of the gill chamber in the adult phase. A similar fact was observed by Gifford (1962) for Cardisoma guanhumi (Latreille, 1825), permitting a characterization of three morphotypes for this species. The CLxCW relationship could be used as an important character to propose morphotypes, since the juveniles' growth was different between the sexes and the adult phase could be represented by a single equation (Table 3). Branco (1993) recorded isometric growth in $U$. cordatus using a linear function $(y=a+b x)$, similar observed by other authors (Botelho et al., 1999; Ivo et al., 1999; Vasconcelos et al., 1999). However, these authors did not subject this biometric relationship data to statistical analyses that could recognize differences in allometric growth between the developmental phases. Dalabona et al. (2005) studied this biometric relationship for this species, but were not observed a difference in growth rates during the ontogeny. This pattern was registered by these authors, probably due to the reduced number of individuals used in their biometric regression analyses.

There are few published studies of the morphometric relationships between gonopod size and the carapace, particularly in regard to the $2^{\text {nd }}$ gonopod pair. The two gonopod pairs of $U$. cordatus showed a growth type similar to "A" described by Somerton (1980), with a distinct cut point between juvenile and adult phases. The same pattern was observed by Haley (1969) for Ocypode quadrata (Fabricius, 1787) and the xanthids Eriphia smithi MacLeay 1838 and E. gonagra (Fabricius, 1781), studied by Vaninni and Gherardi (1988) and Góes and Fransozo (1997), respectively.

Hartnoll (1965) and Flores and NegreirosFransozo (1999) also observed a low growth rate of the $1^{\text {st }}$ gonopod pair after puberty in grapsid crabs. This slow growth could be a reproductive advantage, because males could copulate with females of a wide range of sizes, improving their reproductive output (Hartnoll, 1974). Male brachyurans use this abdominal appendix as a copulatory organ, this structure protects the $2^{\text {nd }}$ gonopod pair, which is smaller and poorly calcified, and it is incapable by itself of executing the mating (Pinheiro and Fransozo, 1999). Males showed the $1^{\text {st }}$ gonopod pair size at the same 
proportion of adults with $31.9 \mathrm{~mm} \mathrm{CW}$, but they required other characters such as a larger chela and mature gonads for mating success (Góes et al., 2000). Haley (1969) observed a coincidence between the allometric changes in the $1^{\text {st }}$ gonopod pair and the size at gonadal maturity for males of Ocypode quadrata. However, in U. cordatus the $2^{\text {nd }}$ gonopod pair showed a better association with gonadal maturation. The inflection point size obtained $(50.7 \mathrm{~mm})$ was near that estimated by male gonadal maturity, according to Hattori and Pinheiro (submitted).

The PLxCW relationship for both sexes was similar to the "A" growth type described by Somerton (1980), with a $7.3 \%$ increase in the male's chelar propodus length from $51.3 \mathrm{~mm} \mathrm{CW}$.
The same growth pattern was observed for the other males' chelar variable; however, the chelae length was more evident, similar to data for the portunid Arenaeus cribrarius, analyzed by Pinheiro and Fransozo (1993) and U. cordatus by Dalabona et al. (2005). According to Dalabona et al. (2005), the major and minor males chelae show a different pattern in allometric growth rates. The major chela had the same allometry rates throughout the ontogeny, which was observed in the present study. However, the minor chela of $U$. cordatus males studied by those authors, showed a positive allometry in juveniles and isometry in adults, this difference in allometric growth rates became the heterochely in males more evident.

Table 4 - $U$. cordatus (Linnaeus, 1763). Description of morphotypes for each sex, based on the morphometric analyses $(\mathrm{CW}=$ carapace width).

\begin{tabular}{|c|c|c|c|}
\hline Sex & $\begin{array}{l}\text { Developmental } \\
\text { Phase }\end{array}$ & CW intervals (mm) & Description \\
\hline \multirow{4}{*}{ 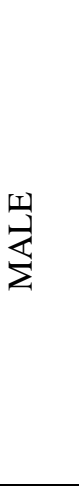 } & Juvenile & $\mathrm{X}^{*} \leq \mathrm{CW} \leq 32$ & $\begin{array}{l}\text { It is possible to identify the sex, but the gonopods, chelae and } \\
\text { carapace show a different growth rate from the adult phase. }\end{array}$ \\
\hline & Pre-puberty & $32 \leq \mathrm{CW} \leq 51$ & $\begin{array}{l}\text { The 1st gonopod pair shows a modification in growth rates } \\
\text { from } 32 \mathrm{~mm}(1.47 \rightarrow 0.95) \text {, while the } 2 \text { nd pair is still growing } \\
\text { at a positive allometric rate. The major propodus chela has not } \\
\text { attained the size of the adult phase. }\end{array}$ \\
\hline & Sub-adult & $51 \leq \mathrm{CW} \leq 59$ & $\begin{array}{l}\text { The 2nd gonopod pair shows a change in growth rate, from } 51 \\
\mathrm{~mm}(1.18 \rightarrow 0.79) \text {, coincident with the high growth rate of the } \\
\text { major propodus chela. }\end{array}$ \\
\hline & Adult & $\mathrm{CW}>59$ & $\begin{array}{c}\text { The carapace is modified by the change in growth rate from } 59 \\
\mathrm{~mm}(0.96 \rightarrow 0.89) \text {. No important modification in body } \\
\text { proportions occurs. }\end{array}$ \\
\hline \multirow{4}{*}{$\sum_{\substack{1\\
}}^{\varliminf_{1}}$} & Juvenile & $\mathrm{X}^{*} \leq \mathrm{CW} \leq 39$ & $\begin{array}{l}\text { It is possible to identify the sex. The abdomen, chela and } \\
\text { carapace still show a different growth rate from the adult } \\
\text { phase. }\end{array}$ \\
\hline & Pre-puberty & $39 \leq \mathrm{CW} \leq 53$ & $\begin{array}{l}\text { Particularly the fifth abdominal somite shows a reduction in } \\
\text { growth rate, from } 39 \mathrm{~mm}(1.79 \rightarrow 1.10) \text {. The propodus chela } \\
\text { still has not reached the adult proportions. }\end{array}$ \\
\hline & Sub-adults & $53 \leq \mathrm{CW} \leq 58$ & $\begin{array}{c}\text { The growth rate of the propodus chela slows from } 53 \mathrm{~mm} \\
(1.22 \rightarrow 1.01) ; \text { even so the carapace has not reached the adult } \\
\text { size. }\end{array}$ \\
\hline & Adults & $\mathrm{CW}>58$ & $\begin{array}{c}\text { The carapace growth rate slows from } 58 \mathrm{~mm}(0.99 \rightarrow 0.84) \text {. } \\
\text { No changes in body structure are observed. }\end{array}$ \\
\hline
\end{tabular}

The high rate of chelae growth in brachyuran males makes the reproductive behavioral display efficient, because they use it to manipulate the females during mating (Hartnoll, 1969; Hazlett, 1975; Pinheiro and Fransozo, 1999). Jivoff (1997a, b) studied the reproductive behavior of Callinectes sapidus, and showed that larger-sized males with large chelae had an advantage in partner selection.
This assumes great importance for semiterrestrial and terrestrial crabs, where visual and tactile stimuli are most important for couple formation (Hartnoll, 1969; Pinheiro and Fransozo, 1999; Góes et al., 2000). According to Góes et al. (2000), during the mating period, the male of $U$. cordatus uses the major chela to strike another male's carapace when they fight over a female. 
Another hypothesis is of sex recognition by the males' chelae size, because females showed $17 \%$ reduction of chelae growth rates at $52.6 \mathrm{~mm} \mathrm{CW}$, whereas the inverse occurred in males of similar size.

In brachyurans, the relative growth of the abdomen has been used only to estimate the females' size at puberty, because certain somites showed striking modification in growth and morphology during ontogeny (Huxley and Richards, 1931), whereas similar changes were not observed in males (Hartnoll, 1974). Development of this female body structure serves to bring them to an efficient size and shape to carry and protect the incubating eggs (Simons, 1981). In males, the abdomen is only used as a support structure for the pleopods, with a copulatory function (Pinheiro and Fransozo, 1993).

All the biometric relationships for $U$. cordatus characterized by two regression lines allowed us to distinguish four morphotypes in this species: juvenile, pre-puberty, sub-adults and adults. In Table 4 describes each one in detail. The relative growth was helpful to establishe the morphological maturity of this species. This information could be useful in future studies, for instance projects related to management of this mangrove crab.

\section{ACKNOWLEDGEMENTS}

We thank FAPESP to providing financial support for the Uçá Project (\#1998/6055-0), and CAPES for fellowship to the second author. Thanks are also due to Biologist Ana G. Fiscarelli for the illustrations and her assistance in fieldwork, and to Biologist Maristela D. Baveloni and other members of CRUSTA (Research Group in Crustacean Biology) for their help in fieldwork and laboratory analyses.

\section{RESUMO}

Um total de 2,130 indivíduos de $U$. cordatus $(1,255$ machos e 875 fêmeas) foi coletado em Iguape (SP), Brasil. Cada exemplar foi submetido à biometria das seguintes estruturas: cefalotórax (largura $=\mathrm{CW}$; comprimento $=\mathrm{CL}$; altura $=\mathrm{CD}$ ), quinto somito abdominal (AW), própodo quelar (comprimento $=\mathrm{PL}$; espessura $=\mathrm{PW}$; altura $=\mathrm{PD})$, e $1^{\circ}$ e $2^{\circ}$ par de gonopódios (comprimento $=\mathrm{GL}_{1}$ e $\mathrm{GL}_{2}$ ). $\mathrm{O}$ teste " $\mathrm{t}$ "
Student e "F" de Snedecor foram utilizados para identificar diferenças no grau de alometria e alterações ontogenéticas na taxa de crescimento, respectivamente. As relações CLxCW, PLxCW (ambos os sexos), $\mathrm{GL}_{1} \mathrm{xCW}$ e $\mathrm{GL}_{2} \mathrm{xCW}$ (machos) e $\mathrm{AWxCW}$ (fêmeas), apresentaram ajuste por duas equações representando a fase jovem e adulta $(p<0.01)$. A determinação dos tamanhos indicados pelas relações morfométricas permitiu a divisão de cada sexo em quatro morfotipos. Os machos foram classificados como jovens $(\mathrm{CW} \leq 32 \mathrm{~mm})$, pré-púberes $(32 \leq \mathrm{CW} \leq 51 \mathrm{~mm})$, subadultos $(51 \leq \mathrm{CW} \leq 59 \mathrm{~mm})$ e adultos $(\mathrm{CW}>59 \mathrm{~mm})$, com tamanho similar ao dos morfotipos das fêmeas (jovens $\mathrm{CW} \leq 39 \mathrm{~mm}$; pré-púberes $39 \leq \mathrm{CW} \leq 53 \mathrm{~mm}$; sub-adultas $53 \leq \mathrm{CW} \leq 58 \mathrm{~mm}$; adultas $\mathrm{CW}>58 \mathrm{~mm}$ ).

\section{REFERENCES}

Aguilar, A. T. and Espina, P. A. (1988), Observaciones biologicas sobre Mursia gaudichaudi (H. Milne Edwards, 1837) capturada en Valparaíso, Chile (Decapoda, Brachyura, Calappidae). Cienc. Tec. Mar, 12, 33-59.

Barnes, R. S. K. (1968), Relative carapace and chela proportions in some ocypodid crabs (Brachyura, Ocypodidae). Crustaceana, 14,131-136.

Botelho, E. R. O.; Dias, A. F. and Ivo, C. T. C. (1999), Estudo sobre a biologia do caranguejo Uca, Ucides cordatus cordatus (Linnaeus, 1763), capturado nos estuários dos Rios Formoso (Rio Formoso) e Ilhetas (Tamandaré), no Estado de Pernambuco. Bol. Tec. Cient. CEPENE, 7: (1), 117-145.

Branco, J. O. (1993), Aspectos bioecológicos do caranguejo Ucides cordatus (Linnaeus, 1763) (Crustacea, Decapoda) do manguezal do Itacorubi, Santa Catarina, Brasil. Arq. Biol. Tecnol., 36: (1), 133-148.

Crane, J. (1941), On the growth and ecology of brachyuran crabs of the genus Ocypode. Zoologica, 26, 297-310.

Dalabona, G.; Silva, J. L. and Pinheiro, M. A. A. (2005), Size at morphological maturity of Ucides cordatus (Linnaeus, 1753) (Brachyura, Ocypodidae) in the Laranjeiras Bay, Southern Brazil. Braz. Arch. Biol. Tech., 48: (1), 139-145.

Davidson, R. J. and Marsden, I. D. (1987), Size relationships and relative growth of the New Zealand swimming crab Ovalipes catharus (White, 1843). J. Crust. Biol., 7: (2), 308-317.

Finney, W. C. and Abele, L. G. (1981), Allometric variation and sexual maturity in the obligate coral commensal Trapezia ferruginea Latreille (Decapoda, Xanthidae). Crustaceana, 41: (2), 113-130. 
Flores, A. A. V. and Negreiros-Fransozo, M. L. (1999), Allometry of the secondary sexual characters of the shore crab Pachygrapsus transversus (Gibbes, 1850) (Brachyura, Grapsidae). Crustaceana, 72: (9), 10511066.

Frith, D. W. and Brunenmeister, S. (1983), Fiddler crab (Ocypodidae: genus Uca) size, allometry and male major chela handedness and morphism on a Thailand mangrove shore. Phuket mar. Biol. Cent. Res. Bull., 29, 1-16.

Gifford, C. (1962), Some observation on the general biology of the land crab, Cardisoma guanhumi (Latreille) in South Florida. Biol. Bull., 123, 207-223.

Góes, J. M. and Fransozo, A. (1997), Relative growth of Eriphia gonagra (Fabricius, 1781) (Crustacea, Decapoda, Xantidae) in Ubatuba, State of São Paulo, Brazil. Nauplius, 5: (2), 85-98.

Góes, P.; Sampaio, F. D. F.; Carmo, T. M. S.; Toso, G. C. and Leal, M. S. (2000), Comportamento e período reprodutivos do caranguejo do mangue Ucides cordatus. Anais do quinto Simpósio de Ecossistemas Brasileiros, Conservação. Universidade Federal Espírito Santo, Vitória, Brazil. v. 2. pp. 335-348.

Hagen, H. O. von (1987), Allometric growth in two populations of Uca tangeri from the Guadalquivir estuary (Andalusia). Invest. Pesq., 51: (1), 443-452.

Haley, S. R. (1969), Relative growth and sexual maturity of the Texas ghost crab, Ocypode quadrata (Fabr.) (Brachyura, Ocypodidae). Crustaceana, 17: (3), 285-297.

Haley, S. R. (1973), On the use of morphometric data as a guide to reproductive maturity in the ghost crab, Ocypode cerotophthalmus (Pallas) (Brachyura, Ocypodidae). Pac. Sci., 27: (4), 350-362

Hartnoll, R. G. (1965), Notes on the marine grapsid crabs of Jamaica. Proc. Linn. Soc. London, 176: (2), 113-147.

Hartnoll, R. G. (1969), Mating in Brachyura. Crustaceana, 16, 161-181.

Hartnoll, R. G. (1974), Variation in growth pattern between some secondary sexual characters in crabs (Decapoda, Brachyura). Crustaceana, 27(2), 131136.

Hartnoll, R. G. (1978), The determination of relative growth in Crustacea. Crustaceana, 34(3), 281-293.

Hartnoll, R. G. (1982), Growth. In: Abele, L. G. (Ed.). The Biology of Crustacea, Embryology, Morphology and Genetics. New York: Academic Press. pp. 111-196.

Hattori, G. Y. and Pinheiro, M. A. A. (Submitted), Sexual maturity of the mangrove crab Ucides cordatus (Linnaeus, 1763) (Crustacea, Brachyura, Ocypodidae) at Iguape, São Paulo, Brazil. Fish. Bull.

Hazlett, B. A. (1975), Ethological analyses of reproductive behavior in marine Crustacea. In: European Marine Biology Symposium, Sorrento (Naples), 8., Italy. Annals... Italy. pp. 1-19.
Huber, M. E. (1985), Allometric growth of the carapace in Trapezia (Brachyura, Xanthidae). J. Crust. Biol., 5: (1), 79-83.

Huxley, J. S. (1924), The variation in the width of the abdomen in immature fiddler crabs considered in relation to its relative growth rate. Am. Nat., 58, 468-475.

Huxley, J. S. (1950), Relative growth and transformation. Proc. R. Soc. London (B), 137, 465-469.

Huxley, J. S. and Richards, O. W. (1931), Relative growth of the abdomen and the carapace of the shorecrab Carcinus maenas. J. Mar. Biol. Ass. U. K., 17: (3), 1001-1015.

Ivo, C. T. C.; Dias, A. F. and Mota, R. I. (1999), Estudo sobre a biologia do caranguejo-uçá Ucides cordatus cordatus, (Linnaeus, 1763), capturado no Delta do Rio Parnaíba, Estado do Piauí. Bol. Tec. Cient. CEPENE, 7: (1), 53-84.

Jivoff, P. (1997a), Sexual competition among male blue crab, Callinectes sapidus. Biol. Bull., 193, 368-380.

Jivoff, P. (1997b), The relative roles of predation and sperm competition on the duration of the postcopulatory association between the sexes in the blue crab, Callinectes sapidus. Behav. Ecol. Sociobiol., 40, 175-185.

Kuris, A. M.; Ra'anan, Z.; Sagi, A. and Cohen, D. (1987), Morphotypic differentiation of male Malaysian giant prawns, Macrobrachium rosenbergii. J. Crust. Biol., 7: (2), 219-237.

Melo, G. A. S. (1996), Manual de Identificação dos Brachyura (caranguejos e siris) do Litoral Brasileiro, 1st ed. São Paulo, Plêiade/FAPESP.

Miller, D. C. (1973), Growth in Uca. 1. Ontogeny of asymmetry in Uca pugilator (Bosc) (Decapoda, Ocypodidae). Crustaceana, 24, 119-131.

Negreiros-Fransozo, M. L.; Colpo, K. D. and Costa, T. M. (2003), Allometric growth in the fiddler crab Uca thayeri (Brachyura, Ocypodidae) from a subtropical mangrove. J. Crust. Biol., 23: (2), 273-279.

Pinheiro, M. A. A. and Fransozo, A. (1993). Relative growth of the speckled swimming crab Arenaeus cribrarius (Lamarck, 1818) (Brachyura, Portunidae), near Ubatuba, State of São Paulo, Brazil. Crustaceana, 65: (3), 377-389.

Pinheiro, M. A. A. and Fransozo, A. (1998), Sexual maturity of the speckled swimming crab Arenaeus cribrarius (Lamarck, 1818) (Decapoda, Brachyura, Portunidae) in the Ubatuba littoral, São Paulo State, Brazil. Crustaceana, 71: (4), 434-452.

Pinheiro, M. A. A. and Fransozo, A. (1999), Reproductive behavior of the swimming crab Arenaeus cribrarius (Lamarck, 1818) (Crustacea, Brachyura, Portunidae) in captivity. Bull. Mar. Sci., 64: (2), 243-253. 
Rodrigues, A. M. T.; Branco, E. J.; Saccardo, S. A. and Blankeystein, A. (2000), Explotação do caranguejo Ucides cordatus (Decapada: Ocypodidae) e o processo de gestão participativa para normatização da atividade na região sudeste-sul do Brasil. Bol. Inst. Pesca, 26: (1), 63-78.

Santos, E. P. (1978), Dinâmica de populações aplicada à pesca e piscicultura. São Paulo: HUCITEC/EDUSP.

Santos, M. C. F. and Garcia-Mendes, E. (1982), Biometric studies and mechanical advantages in the dimorphic chelae of the mangrove crab, Ucides cordatus. Bol. Fisiol. Anim. USP, 6,143-150.

Simons, M. J. (1981), Relative growth in the New Zealand mud crab Macrophthalmus hirtipes (Brachyura: Ocypodidae). N. Z. J. Mar. Fresh. Res., 15, 193-200.

Sokal, R. R. and Rohlf, F. J. (1995), Biometry: the principle and practice of statistics in biological research. $3^{\text {rd }}$ ed. New York: W.H. Freeman.

Somerton, D. A. (1980), A computer technique for estimating the size of sexual maturity in crabs. Can. J. Fish. Aquat. Sci., 37, 1488-1494.

Somerton, D. A. and MacIntosh, R. A. (1983), The size at sexual maturity of blue king crab, Paralithodes platypus, in Alaska. Fish. Bull., 81: (3), 621-628.

Vannini, M. and Gherardi, F. (1988), Studies on the pebble crab, Eriphia smithi MacLeay 1838 (Xanthoidea, Menippidae): Patterns of relative growth and population structure. Trop. Zool., 1, 203-216.

Vasconcelos, E. M. S.; Vasconcelos, J. A. and Ivo, C. T. C. (1999), Estudo sobre a biologia do caranguejo Uçá, Ucides cordatus cordatus (Linnaeus, 1763), capturado no estuário do Rio Curimatau (Canguaretama) no Estado do Rio Grande do Norte. Bol. Téc. Cient. CEPENE, 7: (1), 85-116. 